\title{
Health Problems of Nepalese Migrant Workers and Their Access to Healthcare Services in Three Countries of Middle East
}

*Damaru Prasad Paneru, Chiranjivi Adhikari, Raju Pandey, Bimala Bhatt, Manisha Chalise, Nirdesh Baidhya, Arati Paudel

School of Health and Allied Sciences, Faculty of Health Sciences, Pokhara University, Nepal

*Corresponding Author: Dr Damaru Prasad Paneru; Email: damaru.paneru@gmail.com

\begin{abstract}
Background: Migrants' health is a global public health issue. Middle East countries are the major destination for abroad job among Nepalese workers. This study carried out to identify the health problems among migrant workers and their access to health care in Saudi Arabia, United Arab Emirates (UAE) and Qatar of Middle East.

Methods: This was a cross-sectional study; carried out among 480 returnee migrant workers who have given consent for the study. Data were collected at Tribhuvan International Airport (October 2018) using pretested structured interview schedule after taking approval from Institutional Review Committee of Pokhara University. Data were analyzed using SPSS 20 version. Percentage, mean/median, standard deviation, Chi square test and logistic regression performed.

Results: Majority of the returnee migrants workers were male (95.0\%) and their mean age was $32.38 \pm 5.54$ years. Almost ten percent of the participants suffered from at least one health problem during their stay in Middle East; among them, respiratory problems were common (35.6\%). Almost all participants (99.6\%) had health policy to take care of migrant workers and 93.5 percent participants had health insurance coverage. Female workers (AOR 4.34; CI: 1.54-12.19), and migrants who worked for additional benefits (AOR 2.17; CI: 1.11-4.25) had significantly higher prevalence of health problems than their counterparts $(\mathrm{P}<0.05)$.

Conclusion: Almost ten percent migrant workers had at least one health problem during their stay in Saudi Arabia, UAE and Qatar. Almost all workers had the access to health care in Middle East countries. Female workers and the workers who performed additional work (over time) were at higher risk of the health problems. Universal coverage of quality health care for migrant workers in abroad and mainstreaming the route of permission for work is recommended.
\end{abstract}

Keywords: Health Problems, Nepalese, Migrant workers, Health care, Middle East

\begin{tabular}{|c|c|c|}
\hline \multicolumn{2}{|c|}{ Access this article Online } & Article Info. \\
\hline Quick Response Code & Website: & How to cite this article in Vancouver Style? \\
\hline & www.jkahs.org.np & $\begin{array}{l}\text { Paneru D, Adhikari C, Pandey R, Bhatt B, Chalise } \\
\text { M, Baidhya N, Paudel A. Health Problems of Nepa- } \\
\text { lese Migrant Workers and Their Access to Healthcare } \\
\text { Services in three countries of Middle East. Journal of } \\
\text { Karnali Academy of Health Sciences 2020;3(2):36-40 }\end{array}$ \\
\hline \& Vie & $\begin{array}{l}\text { DOI: } \\
\text { https://doi.org/10.3126/ } \\
\text { jkahs.v3i2.30856 }\end{array}$ & $\begin{array}{ll}\text { Received } & : 12 \text { February } 2020 \\
\text { Accepted } & : 25 \text { June } 2020 \\
\text { Published Online } & : \text { 26 June } 2020 \\
& \\
\text { Conflict of Interest } & : \text { None } \\
\text { Source of Support } & : \text { None }\end{array}$ \\
\hline
\end{tabular}




\section{BACKGROUND}

Political instability following 1990's public movement led the emergence of decade long insurgence in Nepal. It increased the sense of insecurity, joblessness and economic recession; resulting in migration of productive age group population for employment and security. ${ }^{1,2}$ Ministry of Labor and Employment, Nepal, reported that 86.42 percent of all labor migrants during 2008-2016 had issued their visa for Gulf Council Countries (GCC) and Malaysia. ${ }^{3}$ Among all permissions granted, majority of them were issued for Malaysia, United Arab Emirates (UAE), Qatar and Saudi Arabia. It indicates that Gulf countries are major destinations for Nepalese migrant workers for international employment. ${ }^{4}$ Considering the high demand of the labor workforce aboard, Government of Nepal introduced the Foreign Employment Policy in 2012. The policy envisioned the goal to ensure safe, organized, respectable and reliable foreign employment to contribute to poverty reduction along with sustainable economic and social development through economic and non-economic benefits of foreign employment. ${ }^{5}$ To safeguard the health of the Nepali migrants abroad, the policy has made the provisions of pre-placement examination of health and defined service schemes for them. ${ }^{5,6}$

Despite the various efforts made by Government of Nepal for promoting the social security and health status of migrant workers, high prevalence of health problems and occupational injuries, suicides and psychological problems were reported among the migrants who worked in Middle East countries. Nevertheless, most Nepalese migrant workers do not have good access to healthcare facilities including health insurance facility. ${ }^{4,6,7}$

Increasing movement of people across the globe for foreign employment has become a contemporary global public health issue. ${ }^{4}$ Therefore, the present study was carried out to identify the health problems of the Nepalese migrant workers and their access to health care in the three selected major destinations for employment among Nepalese migrants namely UAE, Saudi Arabia and Qatar.

\section{MATERIALS AND METHODS}

This was a cross-sectional analytical and quantitative study, carried out at Tribhuvan International Airport (TIA), arrival gate 6, Kathmandu, Nepal. A total of 480 consenting Nepalese migrant workers who had worked at least for six months in any of three members of Middle East counties: Qatar, Saudi Arabia and UAE; who returned either on leave or with completed job tenure or terminated their work arriving at TIA between 7.00 AM to 6.00 PM in the month of October 2018 were enrolled for the study. Data were collected by trained postgraduate students of public health using pretested structured interview schedule and face-to-face interview was organized with the migrant workers. Collected data were entered into Epidata and data analysis was done using SPSS 20 version. Percentage, mean, median, range, Chi square test and logistic regression analysis were performed to infer findings. Ethical approval was obtained from Institutional review committee of Pokhara University.

\section{RESULTS}

Majority of the returnee migrant workers were male (95.0\%), their mean age was $32.38 \pm 5.54$ years and 58 percent of them belonged to joint families. Almost half $(47.7 \%)$ of them were returned from Qatar followed Saudi Arabia (26.5\%) and UAE (25.8\%). Only 6 percent participant had past experiences of working in the countries of Middle East. Majority (85.0\%) of the participants entered to the Middle East through registered companies and 15 percent of them employed through the agents (Table 1).

\section{Table 1: Background characteristics of mi- grant workers $(n=480)$}

\begin{tabular}{|l|l|l|}
\hline \multicolumn{2}{|c|}{ Variables } \\
\hline Gender \\
\hline Male & 456 & 95.0 \\
\hline Female & 24 & 5.0 \\
\hline Age (in years) & 52 & 10.8 \\
\hline$\leq 25$ & 308 & 64.2 \\
\hline $26-35$ & 120 & 25.0 \\
\hline$>35$ & \multicolumn{2}{|l}{ Min $=24$ and Max $=45$} \\
\hline Mean $=32.38 \pm 5.540$,
\end{tabular}




\begin{tabular}{|l|l|l|}
\hline Type of Family & 201 & 41.9 \\
\hline Single & 279 & 58.1 \\
\hline Joint & 229 & 47.7 \\
\hline Country of work & 127 & 26.5 \\
\hline Qatar & 124 & 25.8 \\
\hline Saudi Arabia & \begin{tabular}{l}
$|l|$ \\
\hline UAE
\end{tabular} & 29 \\
\hline $\begin{array}{l}\text { Worked in the middle east countries before the } \\
\text { present work }\end{array}$ & 6.0 \\
\hline Yes & 451 \\
\hline No & 408 & 85.0 \\
\hline Mode of entry in middle east country \\
\hline $\begin{array}{l}\text { Through } \\
\text { companies }\end{array}$ & 72 & 15.0 \\
\hline Through Agents & 72 \\
\hline
\end{tabular}

Majority $(68.8 \%)$ of the participants had worked in these countries for $\leq 50$ months (median time 36 months). Almost nine out of every ten participants $(88.8 \%)$ worked $\leq 10$ hours a day and 50.8 percent of them had worked on overtime. Out of those over time workers, 96.7 percent of them had worked for $\leq 6$ hours in a day (median: 4 hours).

More than three-fourths (76.9\%) of the participants had performed non-technical work whereas almost a quarter (23.1\%) of them had done technical works of their fields (Table 2).

Table 2: Work experiences of migrant workers $(n=480)$

\begin{tabular}{|l|l|l|}
\multicolumn{3}{|c|}{ Variables } \\
\hline Duration of work in the country (in months) \\
\hline$\leq 50$ & 330 & 68.8 \\
\hline $51-100$ & 100 & 20.8 \\
\hline$>100$ & 50 & 10.5 \\
\hline $\begin{array}{l}\text { Median= 36, Min=6 } \\
\text { and Max=240 }\end{array}$ & & \\
\hline Hours to work/day & 426 & 88.8 \\
\hline$\leq 10$ hours & 54 & 11.3 \\
\hline$>10$ hours & \\
\hline $\begin{array}{l}\text { Median=8, Min=8 } \\
\text { and Max=12 }\end{array}$ & & \\
\hline $\begin{array}{l}\text { Additional hours of } \\
\text { work (over time) }\end{array}$ & & 50.8 \\
\hline Yes & 244 & 49.2 \\
\hline No & 236 & \\
\hline
\end{tabular}

\begin{tabular}{|l|l|l|}
\hline $\begin{array}{l}\text { Additional working } \\
\text { hours }(\mathrm{n}=244)\end{array}$ & & \\
\hline$\leq 6$ hours & 236 & 96.7 \\
\hline$>6$ hours & 8 & 3.3 \\
\hline $\begin{array}{l}\text { Median =4 Min=2 } \\
\text { and Max=6 }\end{array}$ & & \\
\hline $\begin{array}{l}\text { Type of work* } \\
\text { Non-technical }\end{array}$ & 369 & 76.9 \\
\hline Technical & 111 & 23.1 \\
\hline
\end{tabular}

*Technical work: work related to the skills and proficiency of the workers

Almost ten percent of the participants had at least one health problem during their stay in Middle East countries; among them, 35.6 percent had respiratory diseases followed by skin related conditions (17.8\%), musculoskeletal problems $(15.6 \%)$, gastritis $(11.1 \%)$ and others (28.9\%). Majority (80.8\%) of the participants perceived that their occupation was safe whereas 15.2 percent of them perceived that their occupation was risky (Table 3 ).

Almost all participants (99.6\%) reported that there was the health policy to take care of migrant workers. About 93.5 percent of the participants had health insurance for the working period. They stated that there were the provisions of emergency services (97.7\%) and ambulance services (96.7\%) for workers at the workplace. In addition, 57.9 of them reported that there was mechanism for periodic health checkup at workplace (Table 3).

Table 3: Health problems and access to health care among migrant workers $(n=480)$

\begin{tabular}{|l|l|l|}
\multicolumn{2}{|c|}{ Variables Frequency } & Percentage \\
\hline Suffer from any disease & 46 & 9.6 \\
\hline Yes & 434 & 90.4 \\
\hline No & \\
\hline Type of disease & 16 & 35.6 \\
\hline Respiratory diseases & 16 & 17.8 \\
\hline Skin related problems & 8 & 15.6 \\
\hline $\begin{array}{l}\text { Musculo skeletal } \\
\text { problems }\end{array}$ & 7 & 11.1 \\
\hline Gastritis & 5 & 28.9 \\
\hline Others & 13 & 4.0 \\
\hline Perceived safety at the present work & 19 & \\
\hline Highly safe & 19 & \\
\hline
\end{tabular}




\begin{tabular}{|l|l|l|}
\hline Safe & 388 & 80.8 \\
\hline Risky & 73 & 15.2 \\
\hline \multicolumn{3}{|l|}{ Health policy to take care of migrant workers } \\
\hline Yes & 478 & 99.6 \\
\hline No & 2 & 0.4 \\
\hline Have health insurance in the working country \\
\hline Yes & 449 & 93.5 \\
\hline No & 31 & 6.5 \\
\hline Availability of emergency service \\
\hline Yes & 469 & 97.7 \\
\hline No & 11 & 2.3 \\
\hline Availability of ambulance service \\
\hline Yes & 464 & 96.7 \\
\hline No & 16 & 3.3 \\
\hline Periodic health checkup of workers \\
\hline Yes & 278 & 57.9 \\
\hline No & 178 & 37.1 \\
\hline Don't know & 24 & 5.0 \\
\hline
\end{tabular}

Bivariate analysis using Chi square test revealed that there was significant differences in the occurrence of health problems by gender, smoking habit and additional hours of work $(\mathrm{P}<0.05)$; nevertheless age of the migrant worker, income status, the type of family, country, duration and type of work; monthly income, total working hours, nature of work, distance of residence from workplace, mode of travel, alcohol consumption; satisfaction with the work and perception of health risk did not show any association with the occurrence of health problems.

Factors which were statistically associated with the health problems at bi-variate analysis were further subjected for multivariate regression analysis. After controlling all the potential confounders, sex and the additional work for extra benefits were found to be the important factors associated with the health problems among migrant workers (Table 4).

Table 4: Multivariate regression model for factors associated with health problems

\begin{tabular}{|c|c|c|c|c|}
\hline \multirow[t]{2}{*}{ Variables } & \multirow[t]{2}{*}{ Pvalue } & \multirow[t]{2}{*}{$\begin{array}{l}\text { Odds } \\
\text { ratio }\end{array}$} & \multicolumn{2}{|c|}{$\begin{array}{c}\text { Confidence } \\
\text { Interval }\end{array}$} \\
\hline & & & Lower & Upper \\
\hline \multicolumn{5}{|l|}{ Sex } \\
\hline Female & \multirow[t]{2}{*}{0.005} & 4.34 & 1.54 & 12.19 \\
\hline Male & & 1 & & \\
\hline
\end{tabular}

\begin{tabular}{|l|l|l|l|l|}
\hline Smoking \\
\hline Yes & 0.10 & 1.82 & 0.88 & 3.77 \\
\hline No & \multicolumn{5}{l|}{1} & & \\
\hline Work for additional benefits \\
\hline Yes & 0.02 & 2.17 & 1.11 & 4.25 \\
\hline No & & 1 & & \\
\hline
\end{tabular}

Nagelkerke's R-square $=0.09, \mathrm{P}$ value $<0.05$ considered significant

\section{DISCUSSION}

Present study revealed that nearly one out of every ten migrant workers had experienced at least one health problem during their stay at host countries of the Middle East. Occurrence of Health problems was lower than that was reported in 2011 and 2018, 4,8 Among the problems experienced, respiratory diseases (35.6\%), dermatitis (17.8\%), musculoskeletal problems $(15.6 \%)$, gastritis $(11.1 \%)$ and others (28.9\%) were frequently reported. Although, the externt of problems was lesser, similar types of problems were reported in different studies ${ }^{4,8,9}$ which were so reported in our study. In the meantime, 15.2 percent participants perceived that their working environment was risky which was lower than that was reported in 2017 (20\%). ${ }^{10}$ Reduced burden of health problems and less perceived risk could be due to pre-orientation program, increased coverage of care and improved safety at work places following the enactment of foreign migration policy $2012 .{ }^{5}$

Almost all participants $(99.6 \%)$ reported that there is the health policy to take care of migrant workers and nine out of every ten $(93.5 \%)$ participants had health insurance for the working period in the Middle East countries. Similar studies reported that one-third to two-thirds of the migrants workers were protected by employers' health and almost three-quarters had registered with a doctor abroad. ${ }^{4,10}$ Increase in the proportion of insurance coverage in this study could be due to improvement in health care coverage over the period of time and implementation of foreign employment policy. Present study showed that that there were the provisions of emergency services $(97.7 \%)$, ambulance services $(96.7 \%)$ available at workplace and three-fifths migrant's workers reported that there was the mechanism for periodic health checkup. 
After controlling all the potential confounders, sex and the additional work for benefits were found to be the important factors associated with the health problems among migrant workers. Females were 4.34 times more likely to have health problems than the counterpart males. Similarly, those migrants who worked for additional benefits had significantly higher prevalence of health problems than those who work for normal working hours. A similar study reported that age, country of work, doctor registration and perceived standard of work environment and accommodation were significantly associated with health problems and accidents at work. ${ }^{10 .}$

\section{CONCLUSION}

Almost ten percent migrant workers had experienced at least one health problem during their stay in the host countries. Almost all workers had the access to health care in and their healthcare was mostly they were catered through health insurance. Gender of the worker and additional work for extra salary were the significant factors associated with the occurrence of health problems among Nepalese migrant workers. However, representation of returnees other than air-route and longer duration of study should be considered before reaching the precise conclusion. Universal coverage of quality health cares for migrant workers in abroad and mainstreaming the route of permission for work is recommended.

Acknowledgements: The research team would like to express special thanks to Pokhara University Research Centre for financial support (Grant No: 115/2073/074) and TIA officials for the granting the permission to conduct study. We are very much indebted to the study participants for their cooperation.

\section{REFERENCES}

1. Bhandari TR, Sarma PS, Kutty VR. Utilization of maternal health care services in post-conflict Nepal. International journal of women's health. 2015;7:783-90. https:/www.ncbi.nlm.nih.gov/ pmc/articles/PMC4554403/

2. Devkota B, Van Teijlingen ER. Understanding effects of armed conflict on health outcomes: the case of Nepal. Conflict and health. $2010 ; 4: 20$.https://1ink.springer.com/ article/10.1186/1752-1505-4-20

3. Ministry of Labor and Employment. Labor Migration for Employment-A Status Report for Nepal: 2015/2016-2016/2017. Google scholar

4. Joshi S, Simkhada P, Prescott GJ. Health problems of Nepalese migrants working in three Gulf countries. BMC international health and human rights. 2011;11:3. https:// bmcinthealthhumrights.biomedcentral.com/ articles/10.1186/1472-698X-11-3

5. Government of Nepal MoLaE. Foreign Employment Policy 2068 BS. Kathmandu: 2012. http://dol.gov.np/ckeditor/kcfinder/upload/files/ ForeignEmploymentPolicy2068eng.pdf

6. Nepal IOM. Health Vulnerabilities of Migrants from Nepal:Baseline Assessment 2015. https:// migrationhealthresearch.iom.int/healthvulnerabilities-migrants-nepal-baseline-assessment

7. Sijapati B, Bhattarai A, Pathak D. Analysis of labour market and migration trends in Nepal: GDC Country Office Nepal, GIZ Kathmandu; 2015.https://un.info.np/Net/NeoDocs/View/7638

8. Simkhada $\mathrm{P}$, van Teijlingen E, Gurung $\mathrm{M}$, Wasti SP. A survey of health problems of Nepalese female migrants workers in the Middle-East and Malaysia. BMC international health and human rights. 2018;18(1):4. https:// bmcinthealthhumrights.biomedcentral.com/ articles/10.1186/s12914-018-0145-7

9. Adhikary P, Keen S, Van Teijlingen E. Workplace accidents among Nepali male workers in the Middle East and Malaysia: A qualitative study. Journal of immigrant and minority health. 2019;21(5):1115-22. https://link.springer.com/ article/10.1007/s10903-018-0801-y

10. Adhikary P, Sheppard ZA, Keen S, Teijlingen Ev. Risky work: Accidents among Nepalese migrant workers in Malaysia, Qatar and Saudi. Health Prospect: Journal of Public Health. 2017;16(2):3-10. https://www.nepjol.info/ index.php/HPROSPECT/article/view/18643 